\title{
Content, Language and Method Integrated Teacher Training (CLMITT) in Training Teachers of English as a Foreign Language (EFL) and Beyond
}

\author{
Orosz, A. ${ }^{1}$ \\ ${ }^{1}$ Universidad Nacional de Educacion, Ecuador \\ Corresponding email: agnes.orosz@unae.edu.ec
}

\begin{abstract}
Content, Language and Method Integrated Teacher Training (CLMITT) is an educational model for teacher training developed by the author. It refers to an approach where trainees learn teaching methodologies through experiencing them while simultaneously integrating English language development into the training process. CLMITT can be used to train teachers in any context where the course content includes teaching strategies, skills, approaches or methods and where trainees also need to learn English (or another foreign language). Therefore, it is a fitting approach for training non-native English speaker teachers. Applying CLMITT involves the teacher trainer teaching a classroom method or technique by using that method itself during training sessions while using materials about that method. In this way, the content of the session and the method used to teach the session are the same, and trainees are not only learning about a teaching model or strategy but also experiencing it in action from a student perspective at the same time. In addition, trainees are also improving their English, since the whole exercise takes place in English. CLMITT can be applied in Initial Teacher Training (ITT) Programs as well as Continuous Professional Development courses. Trainee feedback after a CLMITT session showed that students felt it provided them with a much deeper understanding of the methods, approaches and strategies covered, while at the same time improving their English during the process.
\end{abstract}

Keywords: EFL; Teacher Training; English; CLMITT

DOI: $10.20961 /$ ijpte.v\%vi\%i.16928

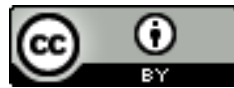

Except where otherwise noted, content on this site is licensed under a Creative Commons Attribution 4.0 International License. 


\section{INTRODUCTION}

Content, Language and Method Integrated Teacher Training (CLMITT) is an educational model for teacher training developed by the author. It refers to using the same teaching method, approach or strategy that trainees are learning about to teach them about that method while simultaneously integrating English language development into the training process. CLMITT can be used to train teachers in any context where the course content includes teaching strategies, skills, approaches or methods and where trainees also need to learn English (or another foreign language). Therefore, it is an ideal approach for training non-native English speaker teachers. Applying CLMITT involves the teacher trainer teaching a classroom method or technique by using that method itself during training sessions and using materials about that method. CLMITT can be applied in Initial Teacher Training (ITT) Programs as well as Continuous Professional Development courses.

Many TESOL (Teaching English to Speakers of Other Languages) degrees concentrate on giving trainees information about teaching, but don't actually develop trainees' teaching skills. A survey undertaken by the author in January 2017 of the curricula of Ecuadorian English teaching degrees, revealed that on average, only $6 \%$ of subjects on these degrees deal with teaching methodology. This means that university students on TESOL degrees in Ecuador, receive a theory-heavy syllabus imparted in a traditional, teacher-centred way and the result is graduates who come out knowing a lot about teaching but not really knowing how to teach. Providing trainees with information about language, language learning and methodology does not necessarily make them better teachers. Students studying to be English teachers in Ecuador also tend to graduate with a low level of English proficiency, in fact, a study found that in 2015, only 1\% of English teachers met the required B2 level of linguistic competence (British Council, 2015). The method I am proposing here for teacher training is one step towards addressing both these two key issues.

\section{WHAT IS CONTENT, LANGUAGE AND METHOD INTEGRATED TEACHER TRAINING?}

Content and Language Integrated Learning (CLIL) is an approach to teaching a foreign language through content related to another subject (e.g. history or mathematics). In a traditional EFL classroom, students practice their reading skills, for example, on a text about football or technology, whereas in a CLIL classroom, in contrast, a reading text would be about whatever subject is being taught through English, so if the subject is history, the reading text would be about whatever is on the syllabus in history for those students that academic year e.g. Henry VIII. The objective of such courses is two-fold; for students to improve their foreign language skills and to acquire the content knowledge related to the subject being learned. Coyle (2010) sums up CLIL as a "dual-focused educational approach in which an additional language is used for the learning of both content and language” (Coyle, Hood \& Marsh, 2010, p. 1). 
The core elements of CLIL, according to Coyle et al. (2010), are the "4Cs"; culture, communication, content and cognition. Other authors, for example Mehisto et al. (2008) mention multiple focus, a safe and rich learning environment, authenticity, active learning, scaffolding and co-operation as the key features of a CLIL course.

CLMITT takes these core CLIL principles as its inspiration, applies them to teacher training for non-native speakers of English and adds another layer; integrating not only "content" and "language" but also "method" into the process. Here the word "method" refers teaching method, approach or strategy that teacher trainees are learning about (which is also the "content”).

Content, Language and Method Integrated Teacher Training (CLMITT) involves using the same teaching method that trainees are learning about, in order to teach them about that method, using material (reading or listening texts, videos etc.) about that method. For example, in a teacher training session on how to teach reading, instead of telling trainees about jigsaw reading activities, the trainer gets them to do a jigsaw reading activity with a text about jigsaw reading activities. Or instead of describing the dictogloss method (see Jacobs and Small, 2003, for a succinct explanation of the dictogloss procedure), the trainer dictates a text about dictogloss using the dictogloss approach. In this way, the content of the session and the method used to teach the session are the same, and trainees are not only learning about a teaching strategy but also experiencing it in action from a student perspective first hand at the same time. All this, of course, is happening in English, which means the trainer can use these methods to actually teach their trainees English at the same time. So, for example, during the jigsaw reading activity, trainees can practice and improve their English reading, listening and speaking skills, and during the dictogloss activity they can improve their grammatical accuracy. As long as the material and activities are designed at an appropriately challenging level for the trainees, these sessions provide an extremely rich and efficient learning experience for trainees, as they are getting so many things at once; to recap, they receive the content (e.g. a text about dictogloss), they experience the method (from a student perspective while their trainer uses this method to teach them) and they receive English tuition (through participating in the language development activities as students).

I believe this method to be an innovative proposal for teacher training, because although teacher trainers do, on occasion, model approaches to their trainees, they invariably do this as if their trainees were language learners, rather than future teachers. In other words, they model the dictogloss method, for example, by using dictogloss to teach a language point either in English or in another foreign language to demonstrate the approach using a text about a random topic. What I am proposing here is to add another layer to such modelling by integrating the content of the training session into the training session too, so rather than the text being a text aimed at EFL students about a random topic e.g. football, the topic (content) of the text is the very teaching method at hand, i.e. in this case; dictogloss. 
Adding another dimension to CLMITT, trainees can be given the opportunity to try out the methods themselves by asking them to plan and teach a session to their peers using the methods recently introduced. For example, while teaching a module on "Approaches and Methods" on a Masters in Applied Linguistics course in Ecuador, I asked trainees to prepare a session in pairs to teach their peers about an EFL teaching approach using the approach itself. Each pair took on one of the methods in Diane Larsen-Freeman's classic Techniques and Principles in Language Teaching (2011). So, a pair of trainees taught the rest of their classmates about the Grammar Translation method through a text about Grammar Translation that we translated. Another pair planned and taught a wonderfully eccentric lesson on Suggestopedia using a text about Suggestopedia delivered through the Suggestopedic method. This way, trainees also become familiar with how it feels to apply the approaches from a teacher perspective. Each student-led session was followed by a reflective stage where trainees discussed the pros and cons of each method from their own experience of teaching using that method, or being a student in such a lesson.

\section{MATERIALS AND METHODS}

What follows is a description of a teacher training session which applied CLMITT for teaching non-native English speaker teacher trainees on an Initial Teacher Training (ITT) Program in Ecuador. The trainees were students in their third semester at the National University of Education (UNAE) studying for a degree in General Basic Education. The content aim of the lesson was differentiation, i.e. the practice of planning and delivering lessons where different students do activities that are in some way matched to their level / ability / preferences or individual needs, and the language aim was comparative adjectives and to practice listening skills.

The session embodies key CLIL principles, i.e. content, communication, cognition, scaffolding, multiple focus, a safe and rich learning environment, authenticity, active learning, and co-operation.

Lead-in: The lesson started with a problem for the trainees to discuss (in English) and try to solve in groups: "You have 27 students in a year 9 high school EFL class. All the students are the same age $(13-14)$ but they all have different levels of English. When doing activities from the course book, some students find the material too difficult and so give up, switch off and misbehave. Some students find the work too easy and so get bored, switch off and misbehave. What can you do to ensure all students are learning and making progress in your lessons?" The subsequent class discussion laid the groundwork for what was to come and activated students' schemata regarding the lesson content.

Main Activity Step 1: In the discussion, trainees mentioned the idea of giving lower level students easier work and higher level students more challenging tasks. Students were then told that they will experience how this can be implemented in a listening lesson. I explained that I have three different worksheets which all relate to a video about differentiation (Differentiation in Teaching and Learning 
retrieved from https://www.youtube.com/watch?v=UkIQ6KiyA5U). I also briefly explained that the worksheets have different levels of challenge:

o Level 1 Worksheet: Added scaffolding: The worksheet includes 2 activities; a gap fill for a key section of the video, and a matching activity where students have to match section headings (typed out in the order presented in the video) and the main ideas associated with those headings. The gap fill is made easier by having fewer gaps than on the other worksheets. This gives students extra processing time in between gaps. The words missing are all common, regular comparative adjectives which learners will be familiar with. There is also a word bank of the missing adjectives in their base form for students to choose from. There are no comprehension questions.

o Level 2 Worksheet: Medium difficulty: This worksheet has 3 activities. A gap fill for the same section of the video but with more gaps than the level 1 worksheet and fewer gaps than level 3. The words missing are all adjectives but include less common and irregular comparative adjectives too, there is no word bank to choose from. The matching activity is a bit more difficult than level 1 because the order of the headings is jumbled up. There are also some straightforward comprehension questions.

o Level 3 Worksheet: Added Challenge: This worksheet also contains 3 activities. The gap fill, with many more words missing than level 1 and 2, not only comparative adjectives, and no word bank. Students will need near native level competence to catch all the words and write them in the gaps fast enough on their first listen. The matching activity is made more challenging by removing the column of the main ideas; students need to write them in themselves using their own words. The comprehension questions require higher-order thinking skills such as inference, deduction, creativity, analysis and evaluation.

Trainees were then asked to each choose a worksheet depending on their level of listening competence, and sit with other trainees who chose the same worksheet, so they are now sitting in homogeneous groups of students with roughly the same English level as themselves.

Step 2: Students were asked to read through their worksheet in groups, discuss any new vocabulary and try to predict answers to the activities. I monitored carefully, giving level-appropriate input where necessary.

Step 3: I then played the video 2 or 3 times, while students filled in the gaps as they listened, in between each listen students within the same group compared answers and discussed their hypotheses about what they heard.

Step 4: The answers to activity 1 and 2 were checked together in class by playing the video again with subtitles. I checked answers to comprehension questions individually by having students hand in their work to me. 
Step 5: Reflection: We re-created the lesson steps together, eliciting the objective of each stage, reflecting on the effectiveness of lesson, their feelings, any pros or cons about the lesson etc. how they could adapt the material or the idea of differentiation so that they can apply it in their teaching practice placement. All trainees were givem copies of all 3 levels of worksheets.

After students experienced the above described session, students were asked to write a paragraph in English comparing their perceptions of the CLMITT session with an imagined session about differentiation delivered by lecture. This activity had the dual purpose of consolidating both the content and language aims of the lesson (since the question elicits the use of comparatives), as well as to provide data for this research.

\section{RESULTS AND DISCUSSION}

CLMITT results in a rich and efficient approach to teacher training, since we are killing three birds with one stone. Trainees receive content about the method as well as an opportunity to improve their English and, at the same time, experience the method first hand. We could argue for a fourth dead bird if we count the trainees themselves using the method to teach the method and thus experiencing it from a teachers' point of view as a fourth layer.

Once students have built up their confidence of using a certain method within their teacher training class, they are ready to experiment with these methods in their teaching practice placements (like most ITT programs, the UNAE degree includes an element of teaching practice (TP)). Trying out the strategies on actual EFL learners and then reflecting on the experience is the final step of CLMITT. At this final stage, trainees demonstrate that they can apply the method, in other words, that they have acquired procedural knowledge of the teaching method at hand. This procedural knowledge makes it much more likely for the method or strategy to be added to their active repertoire of teaching techniques for the rest of their teaching practice and in their future careers as teachers.

In oral and written feedback, trainees reported that they obtained a much deeper understanding and insight into the approaches this way, than the superficial one they would have had if they had simply been told about them or read about them. I believe this is partly because CLMITT aims to improve students' "procedural knowledge" of the techniques and methods, not only their "declarative knowledge". Anderson (1985) describes declarative knowledge as what we know about a given topic, and procedural knowledge, as what we know how to do. This distinction is often made in English language teaching when, for example, we discuss the benefits of the communicative method in contrast to the shortcomings of the Grammar Translation method. The Grammar Translation method consists of trying to teach a foreign language by having students translate texts from and into their first language (L1) and be able to recite grammar rules such as "the present perfect refers to an action that took place in unfinished time". The trouble with this kind of declarative knowledge of grammar is that it bears almost no relation to a students' ability to actually use the present perfect correctly in communication (which is referred to as procedural knowledge). In other words, the fact that a student who can tell you (declare) that the "the present perfect refers to an action that took place in unfinished time", does not mean that they are 
able to proceduralise this knowledge and use the present perfect correctly in conversation. The communicative method was in part developed in response to this issue and focuses on giving students as many opportunities as possible to apply and practice newly acquired grammar or vocabulary in genuine communicative situations, in order to allow students to acquire procedural knowledge.

Similarly, what we achieve by CLMITT is the development of procedural knowledge in our trainees; the development of the knowledge of how to actually apply and use teaching techniques and methods in a classroom. So, rather than simply acquiring the knowledge to declare that for example "the communicative method is better than the grammar translation method", they have the opportunity to experience and try both methods and experience first-hand the reasons for (or even against) such a statement.

\section{CLMITT IN CONTINOUS PROFESSIONAL DEVELOPMENT(CPD)}

CLMITT need not be restricted to Initial Teacher Training. A few weeks ago I attended a CPD "workshop" on the Flipped Classroom which was not itself flipped. This was a pity, as it would have been possible to do so. All attendees had to sign up in advance via email, so it would have been technologically feasible to send us all a link to a short video about the Flipped Classroom to watch ahead of the session. This would have thereby much better demonstrated the main idea of the Flipped Classroom than the trainer-led lecture. In general, I believe all teacher training should follow the same principles that we know lead to effective learning. If we know group work, active and interactive teaching methods lead to more effective learning (Matsushita, 2017) then we ought to be using exactly those methods in our teacher training sessions. To my mind, there is really no excuse for pure lecturing in teacher training at any level.

\section{BEYOND EFL}

The teacher training method I am proposing here need not be restricted to EFL training either. CLMITT lends itself to all kinds of teacher training, because teacher training is (or should be) fundamentally about trainees acquiring the knowledge and skills associated with approaches, methods and strategies to teach their subject in their context.

Currently I am teaching a subject called "Educational Models" at the National University of Education in Ecuador where all the students are trainee teachers, but not necessarily of English. The syllabus covers various historical and current educational approaches and I have consistently used CMITT to teach my students about the models. When we learned about Behaviourism, for example, I had them perform tasks for rewards and if they were too slow they'd receive a (symbolic) punishment. When we learned about Connectivism, I had them set up their own virtual classroom and share resources they found about Connectivism. Then, the students had to research other contemporary models themselves and present them to the class using the model itself, thereby demonstrating through their lesson plan and activities that they can apply the model. 


\section{CONCLUSIONS}

I believe using Content, Language and Method Integrated Teacher Training is an efficient, effective, interactive, student-centred approach with all the language improvement benefits of the CLIL approach. It follows the principle "Show, don't tell” by demonstrating methods rather than simply talking about them, thereby providing trainees with a deeper understanding of the methods, approaches and strategies covered. It allows students to improve their language proficiency while at the same time gaining procedural knowledge of teaching strategies, making it more likely that they will apply them in their future teaching careers.

\section{REFERENCES}

Anderson, J.R. (1985). Cognitive psychology and its implications ( $2^{\text {nd }}$ ed.). New York: W.H. Freeman

British Council (2015). English in Ecuador: An examination of policy, perceptions and influencing factors. Retrieved January 10, 2017, from https://ei.britishcouncil.org/sites/default/files/latin-americaresearch/English\%20in\%20Ecuador.pdf

Coyle, D., Hood, P., \& Marsh, D. (2010). CLIL: Content and language integrated learning. Cambridge, UK: Cambridge University Press.

Matsushita, K. (2017). Deep active learning: Toward greater depth in university education. Singapore: Springer

Mehisto, P., Marsh, D. \& Frigols-Martín, M. J. (2008). Uncovering CLIL: Content and language integrated learning in bilingual and multilingual education. Oxford, UK: Macmillan Education

\section{MATERIALS}

ChrisAshLearn (Producer) (2012, June 12) Differentiation in Teaching and Learning Retrieved January 10, 2017 from https://www.youtube.com/watch?v=UkIQ6KiyA5U

Larsen-Freeman, D. (2011). Techniques and principles in language teaching ${ }^{\text {rd }}$ ed.), Oxford: Oxford University Press

Jacobs, G. and Small, J. (2003) Combining Dictogloss and Cooperative Learning to Promote Language Learning. The Reading Matrix, 3, 1-15, April 2003 retrieved from http://www.readingmatrix.com/articles/jacobs_small/ 